\title{
PENERAPAN PROBLEM BASED LEARNING DALAM MENINGKATKAN HASIL BELAJAR PENDIDIKAN AGAMA ISLAM DI SMP NEGERI 5 PONOROGO
}

\author{
KHOIRIYATUL FARIDA \\ SMP Negeri 5 Ponorogo Jawa Timur \\ Email : Khoiriyatu175farida@gmail.com
}

\begin{abstract}
ABSTRAK
Pada hakekatnya setiap proses pembelajaran akan selalu berkaitan dengan penekanan terhadap penguasaan kompetensi tertentu oleh peserta didik melalui pengalaman belajar. Hal ini mengandung pengertian bahwa dalam proses pembelajaran hendaknya diciptakan pengalaman belajar yang bersifat mengaktifkan peserta didik dan pembelajaran yang inovatif. Di satu sisi hasil belajar sebagai salah satu komponen dalam penilaian pembelajaran tidak hanya dilihat dari adanya deretan angka , tetapi juga terkait dengan proses pembelajarannya. Jika proses pembelajaran dapat berjalan dengan baik maka hasil belajar peserta didik juga dapat menjadi lebih baik. Hasil Penelitian Tindakan Kelas dengan dua siklus ini telah menunjukkan bahwa penerapan Problem Based Learning terbukti dapat meningkatkan keaktifan peserta didik yang bermuara pada peningkatan hasil belajar Pendidikan Agama Islam dan Budi Pekerti terutama pada Kompetensi Dasar Memahami Makna Tata Krama, Sopan Santun dan Rasa Malu pada Peserta Didik Kelas IX D SMP Negeri 5 Ponorogo Tahun Pelajaran 2021 / 2022 . Hal ini didasarkan pada pengamatan proses pembelajaran yang mengalami peningkatan keaktifan peserta didik dari siklus-1 ke siklus-2 dan juga adanya peningkatan hasil belajar peserta didik sehingga ketuntasan secara klasikal dapat tercapai dari siklus -1 sebesar $50 \%$ ke siklus - 2 sebesar $88 \%$. Kata kunci: Pendidikan Agama Islam, Problem Based Learning
\end{abstract}

\section{ABSTRACT}

In essence, every learning process will always be related to the emphasis on mastering certain competencies by students through learning experiences. This implies that in the learning process, learning experiences should be created that are activating students and innovative learning. On the one hand, learning outcomes as a component in learning assessment are not only seen from the number of numbers, but also related to the learning process. If the learning process can run well, the learning outcomes of students can also be better. The results of this Classroom Action Research with two cycles have shown that the application of Problem Based Learning is proven to be able to increase the activity of students which leads to an increase in learning outcomes of Islamic Religious Education and Morals, especially in the Basic Competence of Understanding the Meaning of Manners, Courtesy and Shame in Students. Class IX D SMP Negeri 5 Ponorogo Academic Year 2021 / 2022 . This is based on observations of the learning process which has increased student activity from cycle-1 to cycle- 2 and also an increase in student learning outcomes so that classical completeness can be achieved from cycle -1 by $50 \%$ to cycle- 2 by $88 \%$.

Keywords: Islamic Religious Education, Problem Based Learning

\section{PENDAHULUAN}

Dalam teori pendidikan dinyatakan bahwa setiap proses pembelajaran, guru atau pendidik memiliki fungsi sebagai motivator untuk mempengaruhi peserta didik melakukan serangkaian kegiatan belajar. Dalam hal ini guru atau pendidik harus melakukan dua hal yaitu memperkokoh motivasi peserta didik dan memilih strategi mengajar yang tepat (Daryanto dan Karim, 2017 : 27) yang berujung pada ketercapaian kompetensi yang diharapkan dan hasil belajar yang maksimal. Hasil belajar sebagai salah satu komponen dalam penilaian pembelajaran tidak harus dilihat dari satu sisi saja, artinya hasil belajar itu tidak hanya dilihat dari deretan angka yang merupakan hasil pembelajaran peserta didik, tetapi juga terkait dengan 
proses pembelajarannya. Jika proses pembelajaran dapat berjalan dengan baik maka hasil belajar peserta didik juga dapat menjadi lebih baik. Sebagaimana disebutkan dalam Panduan Penilaian oleh Pendidik dan Satuan Pendidikan bahwa penilaian pembelajaran (aspek pengetahuan) merupakan proses pengumpulan dan pengolahan informasi untuk mengukur proses dan hasil pencapaian kompetensi peserta didik (Kementerian Pendidikan Dan Kebudayaan Direktorat Jendral Pendidikan Dasar dan Menengah Direktorat Pembinaan Sekolah Menengah Pertama, $2016: 39)$

Menurut Ramayulis (2018 : 21) dalam bukunya Metodologi Pendidikan Agama Islam menyatakan bahwa Pendidikan Agama Islam diartikan sebagai suatu upaya secara sadar dan terencana dalam menyiapkan peserta didik untuk mengenal, memahami, menghayati, mengimani, bertaqwa, berakhlak mulia, mengamalkan ajaran agama Islam dari sumber utamanya kitab suci al Qur'an dan Al Hadits, melalui kegiatan bimbingan, pengajaran, latihan serta penggunaan pengalaman.

Merupakan suatu keniscayaan bahwa setiap pembelajaran pasti memiliki tujuan, demikian juga dengan Pendidikan Agama Islam yang memiliki tujuan untuk meningkatkan keimanan, pemahaman, penghayatan dan pengamalan peserta didik tentang agama Islam, sehingga menjadi manusia muslim yang beriman dan bertakwa kepada Alloh SWT, serta berakhlak mulia dalam kehidupan pribadi, bermasyarakat, berbangsa dan bernegara serta untuk melanjutkan pendidikan pada jenjang yang lebih tinggi (Namsa, $2000: 33$ ).

Dalam rangka mencapai tujuan tersebut, setiap lembaga sekolah tentunya membutuhkan adanya guru / pendidik Pendidikan Agama Islam yang profesional yaitu orang yang menguasai ilmu pengetahuan (agama Islam) dan mampu melakukan transfer ilmu/pengetahuan (agama Islam), internalisasi, serta amaliah (implementasi); mampu menyiapkan peserta didik agar dapat tumbuh dan berkembang kecerdasan dan daya kreasinya untuk kemaslahatan diri dan masyarakatnya; mampu menjadi model atau sentral identifikasi diri dan konsultan bagi peserta didik; memiliki kepekaan informasi, intelektual dan moral-spiritual serta mampu mengembangkan bakat, minat dan kemampuan peserta didik, dan mampu menyiapkan peserta didik untuk bertanggung jawab dalam membangun peradaban yang diridhoi oleh Alloh (Muhaimin, $2010: 51$ ).

Disisi lain Pendidikan Agama Islam sebagai salah satu mata pelajaran yang termasuk dalam Kurikulum 2013 dan wajib diajarkan di lembaga sekolah termasuk di SMP Negeri 5 Ponorogo juga memiliki beragam kompetensi yang harus dikuasai oleh peserta didik. Salah satu permasalahan yang dihadapi dalam proses pembelajaran Pendidikan Agama Islam adalah masih adanya daya serap yang belum maksimal dari peserta didik dalam menguasai Kompetensi Dasar dan kurang aktifnya peserta didik dalam mengikuti pembelajaran Pendidikan Agama Islam. Hal ini tampak dari hasil belajar peserta didik yang belum memenuhi ketuntasan secara klasikal. emungkinan disebabkan karena kondisi pembelajaran yang masih menggunakan pendekatan teacher centered, pendekatan yang berpusat pada pendidik ini sulit untuk memungkinkan peserta didik dalam mengembangkan berbagai kecakapan, salah satunya adalah kecakapan berfikir.

Pelaksanaan Pendidikan Agama Islam di lembaga pendidikan SMPN 5 Ponorogo yang menggunakan Kurikulum 2013, dan memiliki alokasi waktu tiga jam pertemuan dalam satu minggu ini, sebagai upaya untuk meningkatkan hasil belajar Pendidikan Agama Islam maka sangat diperlukan adanya inovasi dalam penerapan model pembelajarannya. Pembelajaran yang aktif dan menarik juga diperlukan dalam rangka meningkatkan kemauan dan konsentrasi peserta didik untuk mengikuti pembelajaran. Pendidik dituntut untuk aktif dalam menentukan pendekatan atau strategi proses pembelajaran. Setiap Pendidik harus dapat melihat potensi peserta didik dan mengembangkannya secara maksimal. Adanya proses pembelajaran yang ideal, hal ini dapat memungkinkan terwujudnya hasil belajar peserta didik yang terus meningkat sehingga Kriteria Ketuntasan belajar kelaspun dapat tercapai.

Berdasarkan uraian diatas, penulis mengadakan Penelitian Tindakan Kelas untuk meningkatkan hasil belajar Pendidikan Agama Islam terutama dalam Kompetensi Dasar 


\section{EDUCATOR : Jurnal Inovasi Tenaga Pendidik dan Kependidikan Vol. 1 No. 2 Desember 2021, e-ISSN : 2807-8659 | p-ISSN : 2807-8829}

Memahami Makna Tata Krama, Sopan Santun dan Rasa Malu pada Peserta Didik Kelas IX D SMP Negeri 5 Ponorogo Tahun Pelajaran 2021 / 2022 dengan Problem Based Learning. Penelitian ini termasuk Penelitian Tindakan Kelas. Pengertian Penelitian Tindakan Kelas merupakan bentuk kajian yang sistematis reflektif yang dilakukan oleh guru dengan tujuan untuk memperbaiki kondisi pembelajaran (Laksono dan Siswono, $2018: 4$ )

Problem Based Learning atau Pembelajaran Berbasis Masalah sebagai salah satu model pembelajaran yang bertujuan mendorong siswa untuk belajar melalui berbagai permasalahan nyata dalam kehidupan sehari - hari atau permasalahan yang dikaitkan dengan pengetahuan yang telah atau akan dipelajarinya. Sebagaiman dinyatakan oleh Fathurrohman ( 2017 : 116), Tahapan - tahapan kegiatan Problem Based Learning adalah sebagai berikut : 1. Mengorientasi peserta didik terhadap masalah ; Guru menjelaskan tujuan pembelajaran dan sarana atau logistik yang dibutuhkan. Guru memotivasi peserta didik untuk terlibat dalam aktivitas pemecahan masalah nyata yang dipilih atau ditentukan . 2. Mengorganisasi peserta didik untuk belajar ; Guru membantu peserta didik mendefinisikan dan mengorganisasi tugas belajar yang berhubungan dengan masalah yang sudah diorientasi pada tahap sebelumnya . 3. Membimbing penyelidikan individual maupun kelompok ; Guru mendorong peserta didik untuk mengumpulkan informasi yang sesuai dan melaksanakan eksperimen untuk mendapatkan kejelasan yang diperlukan untuk menyelesaikan masalah. 4. Mengembangkan dan menyajikan hasil karya ; Guru membantu peserta didik untuk berbagi tugas dan merencanakan atau menyiapkan karya yang sesuai sebagai hasil pemecahan maslah dalam bentuk laporan, video atau model. 5. Menganalisis dan mengevaluasi proses pemecahan masalah ; Guru membantu peserta didik untuk melakukan refleksi atau evaluasi terhadap proses pemecahan masalah yang dilakukan. Diharapkan dengan adanya tahapan dalam Problem Based Learning ini akan mewujudkan tujuan dari pembelajaran Pendidikan Agama Islam. Karena pada hakekatnya setiap proses pembelajaran akan selalu berkaitan dengan penekanan terhadap penguasaan kompetensi tertentu oleh peserta didik melalui pengalaman belajar. Hal ini mengandung pengertian bahwa dalam proses pembelajaran tersebut hendaknya diciptakan pengalaman belajar yang bersifat mengaktifkan peserta didik dan pembelajaran yang inovatif. Setiap Pendidik hendaknya memposisikan dirinya sebagai fasilitator dalam arti yang sesungguhnya (Amir, $2015: 11$ )

\section{METODE PENELITIAN}

Penelitian ini menggunakan metode Penelitian Tindakan Kelas yang bertujuan untuk memperbaiki kondisi pembelajaran. Penelitian Tindakan Kelas ini mengacu pada model siklus yang dikembangkan oleh Kemmis dan Mc. Taggart (Akbar, 2009 : 8) Pada model siklus ini, setiap siklusnya terdiri atas: 1. Planning (perencanaan) 2. Acting \& Observsing (tindakan dan pengamatan) 3. Reflecting (refleksi) 4. Revise Plan (perbaikan rencana).

Dalam penelitian ini kegiatan-kegiatan dalam siklus Penelitian Tindakan Kelas dapat dipaparkan sebagai berikut : Pada Siklus-1 terdiri atas 1) Perencanaan, pada tahap perencanaan, peneliti melakukan studi pendahuluan dengan melakukan refleksi terhadap kegiatan pembelajaran Pendidikan Agama Islam dan Budi pekerti terutama untuk meningkatkan Kompetensi Dasar Memahami Makna Tata Krama, Sopan Santun Dan Rasa Malu pada peserta didik kelas IX D SMP Negeri 5 Ponorogo. Selain itu peneliti juga melakukan telaah terhadap dokumen-dokumen tentang prestasi belajar peserta didik. Studi pendahuluan tersebut menghasilkan masalah-masalah proses dan hasil pembelajaran Pendidikan Agama Islam dan Budi Pekerti terutama untuk meningkatkan Kompetensi Dasar Memahami Makna Tata Krama, Sopan Santun Dan Rasa Malu pada peserta didik kelas IX D SMP Negeri 5 Ponorogo. Dalam proses pembelajaran peneliti melihat adanya masalah dalam hal penerapan model pembelajaran yang kurang mengaktifkan peserta didik dan hasil pembelajaran yang belum maksimal dalam memenuhi kriteria ketuntasan klasikal. Berangkat dari masalah di atas, maka pada tahap perencanaan ini peneliti melakukan penyusunan desain pembelajaran yang berupa Rencana Pelaksanaan Pembelajaran (RPP). 2) Pelaksanaan Tindakan dan Observasi. Pada tahap ini 
peneliti mempraktekkan pembelajaran sesuai dengan Rencana Pelaksanaan Pembelajaran yang telah disusun. Peneliti juga membuat catatan hasil pengamatan terhadap kinerja pendidik, aktifitas peserta didik, dan hasil pembelajaran. 3) Refleksi. Berdasarkan hasil pengamatan, peneliti melakukan refleksi terhadap proses dan hasil pembelajaran yang dicapai pada proses tindakan ini. Refleksi ini dilakukan sesudah selesainya pembelajaran. Refleksi yang dimaksud adalah melakukan berfikir ulang terhadap apa yang sudah dilakukan, apa yang belum dilakukan, apa yang sudah dicapai dan apa yang belum dicapai serta menentukan tindakan apa lagi yang perlu dilakukan untuk meningkatkan kualitas proses dan hasil pembelajaran yang akan dilanjutkan pada siklus ke-2. Pada siklus - 2 sebagaimana halnya pada siklus-1, pada siklus-2 ini juga mencakup kegiatan perencanaan, pelaksanaan tindakan dan observasi, refleksi dan perbaikan rencana. Kegiatan pada setiap tahapan pada siklus-2 ini akan disesuaikan dengan masalah-masalah proses dan hasil pembelajaran yang terjadi pada siklus-1, apa yang belum dicapai pada siklus-1 akan ditindak lanjuti pada siklus 2 .

\section{HASIL DAN PEMBAHASAN}

\section{Hasil Penelitian}

Siklus -1 dilaksanakan pada tanggal 15 Oktober 2021, jumlah peserta didik 16 anak dengan kegiatan inti yaitu : 1. Mengorientasi peserta didik pada masalah ; Guru memfokuskan peserta didik untuk mengamati masalah - masalah yang berkaitan dengan Tata Krama, Sopan Santun dan Rasa Malu yaitu sepuluh problem atau masalah yang disajikan kepada peserta didik untuk dicarikan solusinya ; a. Mengapa masih ada sebagian orang muslim yang belum melaksanakan sholat lima waktu, b. Mengapa masih ada sebagian orang muslim yang sudah mampu membayar zakat tetapi belum bersedia untuk mengeluarkannya, c. Mengapa masih ada sebagian orang muslim yang sudah mampu menunaikan ibadah haji tetapi belum bersedia untuk melaksanakannya, d. Mengapa masih ada sebagian orang muslim yang sering melakukan perbuatan dosa, e. Mengapa masih ada sebagian peserta didik yang belum bersikap sopan santun kepada orang tua dan guru, $f$. Mengapa masih ada sebagian peserta didik yang berbicara kasar atau keras kepada orang tua dan guru, g. Mengapa masih ada sebagian peserta didik yang sering melanggar peraturan sekolah, h. Mengapa masih ada sebagian peserta didik yang belum disiplin dalam mengumpulkan tugas sesuai jadwal yang sudah ditentukan, i. Mengapa masih ada sebagian peserta didik yang masih berbohong dalam mengumpulkan tugas ( menyalin tugas milik teman dan mengaku sebagai hasil karyanya, j. Bagaimana dengan kondisi diri kalian masing - masing, apakah kalian sudah termasuk peserta didik yang disiplin atau belum, berikan penjelasannya. 2. Mengorganisasikan kegiatan pembelajaran ; Guru memberikan kesempatan kepada peserta didik untuk menyampaikan berbagai pertanyaan terhadap masalah yang berkaitan dengan Tata Krama, Sopan Santun dan Rasa Malu. 3. Membimbing penyelidikan mandiri ; Guru memberikan kesempatan kepada peserta didik untuk mengumpulkan informasi guna memperoleh data dalam rangka menjawab atau menyelesaikan masalah yang berkaitan dengan Tata Krama, Sopan Santun dan Rasa Malu. 4. Mengembangkan dan menyajikan hasil karya ; Guru memberikan kesempatan kepada peserta didik untuk mempresentasikan data hasil temuannya dan mengasosiasikan data tersebut dengan data peserta didik lain. 5. Analisis dan evaluasi proses pemecahan masalah ; Guru memberikan kesempatan kepada peserta didik untuk menganalisis data setelah adanya proses asosiasi data dari masing - masing peserta didik dan Guru memberikan penguatan dari data hasil pemecahan masalah.

Penulis mengadakan pengamatan terhadap kegiatan pembelajaran siklus - 1 dengan hasil: semua peserta didik masih belum memberikan alternatif jawaban dari problem yang disampaikan kepada mereka. Masing - masing anak hanya memberikan satu jawaban atau solusi dari problem yang disampaikan. Dari jawaban atau solusi yang disampaikan oleh masing - masing peserta didik, memiliki kemiripan antara satu anak dengan yang lain. Hal ini dimungkinkan karena penerapan Problem Based Learning masih merupakan sesuatu yang baru bagi peserta didik sehingga mereka belum terbiasa untuk memberikan alternatif solusi dari problem - problem yang disampaikan kepada mereka. 
Hasil wawancara dengan peserta didik juga menunjukkan bahwa mereka masih kesulitan menemukan alternatif jawaban atau solusi dari problem - problem yang disampaikan kepada mereka dan peserta didik menyampaikan bahwa problem yang disampaikan kepada mereka terlalu banyak sehingga peserta didik kekurangan waktu dengan jadwal yang tersedia

Tabel 1. Hasil Pembelajaran Siklus - 1

\begin{tabular}{|l|l|l|}
\hline Siklus & Nilai Rata-rata Kelas & Prosentase Ketuntasan Klasikal \\
\hline 1 & 69 & 50 \\
\hline
\end{tabular}

Adapun hasil evaluasi tes tulis secara individu pada siklus - 1 ini belum memenuhi kriteria ketuntasan klasikal, karena prosentase ketuntasan belajar kelas $50 \%$ dan nilai rata-rata kelas 69. Penulis memperbaiki kekurangan yang ada pada pembelajaran siklus -1 ini dengan cara mengurangi jumlah problem yang harus diselesaikan dari jumlah sepuluh menjadi tujuh problem yang harus dicarikan solusinya dan memberikan kesempatan kepada peserta didik untuk mencari sebanyak mungkin referensi yang dapat dijadikan sebagai alternatif solusi dari problem yang disampaikan kepada mereka.

Siklus - 2 dilaksanakan pada tanggal 29 Oktober 2021, jumlah peserta didik 16 anak dengan kegiatan inti yaitu : 1. Mengorientasi peserta didik pada masalah ; Guru memfokuskan peserta didik untuk mengamati masalah - masalah yang berkaitan dengan Tata Krama, Sopan Santun dan Rasa Malu yaitu tujuh problem atau masalah yang disajikan kepada peserta didik untuk dicarikan solusinya ; a. Mengapa masih ada sebagian orang muslim yang belum melaksanakan sholat lima waktu, b. Mengapa masih ada sebagian orang muslim yang sudah mampu membayar zakat tetapi belum bersedia untuk mengeluarkannya, c. Mengapa masih ada sebagian orang muslim yang sudah mampu menunaikan ibadah haji tetapi belum bersedia untuk melaksanakannya, d. Mengapa masih ada sebagian orang muslim yang sering melakukan perbuatan dosa, e. Mengapa masih ada sebagian peserta didik yang belum bersikap sopan santun kepada orang tua dan guru, $f$. Mengapa masih ada sebagian peserta didik yang berbicara kasar atau keras kepada orang tua dan guru, g. Mengapa masih ada sebagian peserta didik yang sering melanggar peraturan sekolah. 2. Mengorganisasikan kegiatan pembelajaran ; Guru memberikan kesempatan kepada peserta didik untuk menyampaikan berbagai pertanyaan terhadap masalah yang berkaitan dengan Tata Krama, Sopan Santun dan Rasa Malu. 3. Membimbing penyelidikan mandiri ; Guru memberikan kesempatan kepada peserta didik untuk mengumpulkan informasi untuk memperoleh data dalam rangka menjawab atau menyelesaikan masalah yang berkaitan dengan Tata Krama, Sopan Santun dan Rasa Malu. 4. Mengembangkan dan menyajikan hasil karya ; Guru memberikan kesempatan kepada peserta didik untuk mempresentasikan data hasil temuannya dan mengasosiasikan data tersebut dengan data peserta didik lain. 5. Analisis dan evaluasi proses pemecahan masalah; Guru memberikan kesempatan kepada peserta didik untuk menganalisis data setelah adanya proses asosiasi data dari masing masing peserta didik dan Guru memberikan penguatan dari data hasil pemecahan masalah.

Penulis mengadakan pengamatan pada pembelajaran siklus -2 dengan hasil : hampir semua peserta didik sudah memberikan alternatif jawaban dari problem yang disampaikan kepada mereka. Masing - masing anak sudah memberikan minimal dua jawaban atau solusi dari problem yang disampaikan. Dari jawaban atau solusi yang disampaikan oleh masing masing peserta didik, memiliki perbedaan dan variatif antara satu anak dengan yang lain. Hal ini dimungkinkan karena Problem Based Learning sudah dikenal oleh peserta didik sehingga bukan lagi dianggap sesuatu yang baru bagi peserta didik sehingga mereka sudah mampu untuk memahami penerapan langkah - langkah Problem Based Learning. Hasil wawancara dengan peserta didik juga menunjukkan bahwa pada siklus -2 ini mereka lebih dapat memahami penerapan Problem Based Learning dan lebih bersemangat dalam memberikan alternatif jawaban atau solusi dari problem yang disampaikan kepada mereka sehingga hal ini juga mempengaruhi terhadap hasil belajar peserta didik. 
Tabel 2. Hasil Pembelajaran Siklus - 2

\begin{tabular}{|l|l|l|}
\hline Siklus & Nilai Rata-rata Kelas & Prosentase Ketuntasan Klasikal \\
\hline 2 & 81 & 88 \\
\hline
\end{tabular}

Adapun hasil evaluasi pembelajaran tes tulis secara individu pada siklus - 2 ini sudah memenuhi kriteria ketuntasan belajar klasikal, karena prosentase ketuntasan belajar kelas $88 \%$ dan nilai rata-rata kelas 81 . Adapun hasil perbandingan siklus -1 dan siklus -2 dapat dilihat pada grafik dibawah ini :

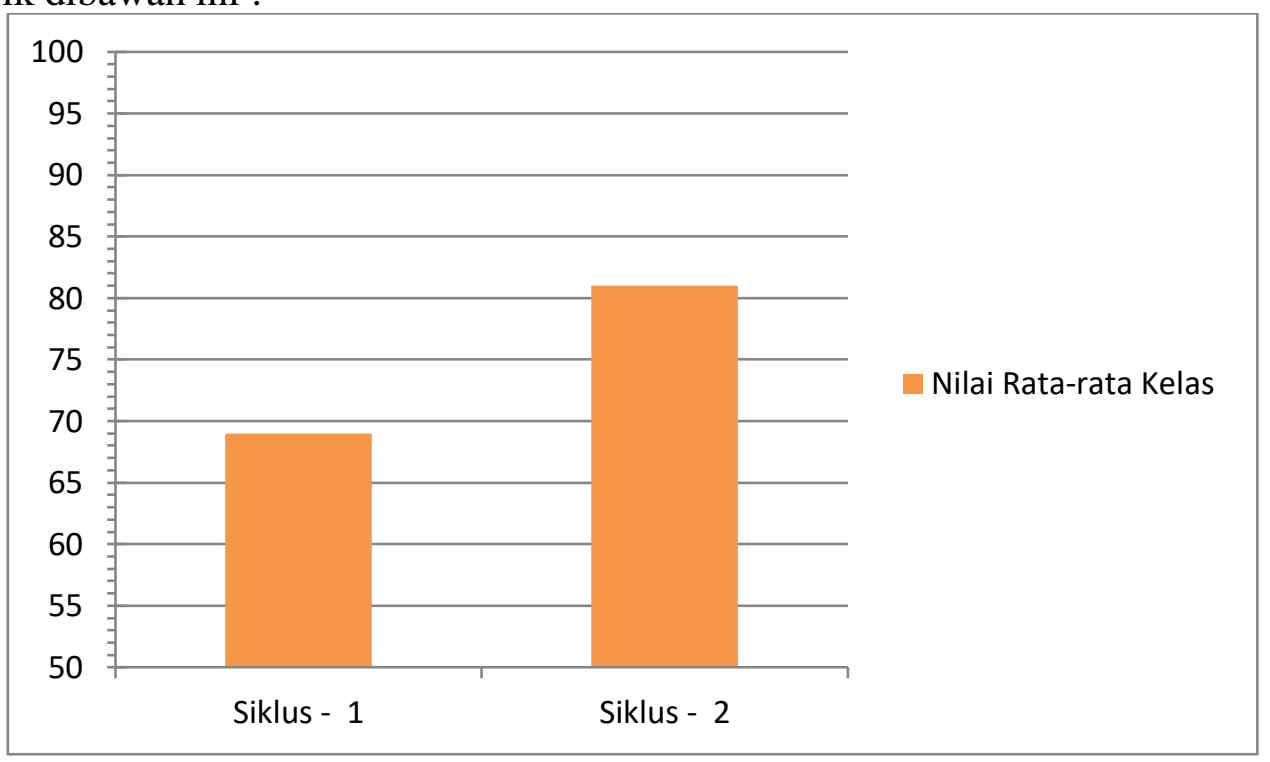

Gambar 1. Hasil perbandingan nilai rata-rata kelas siklus - 1 dan siklus - 2

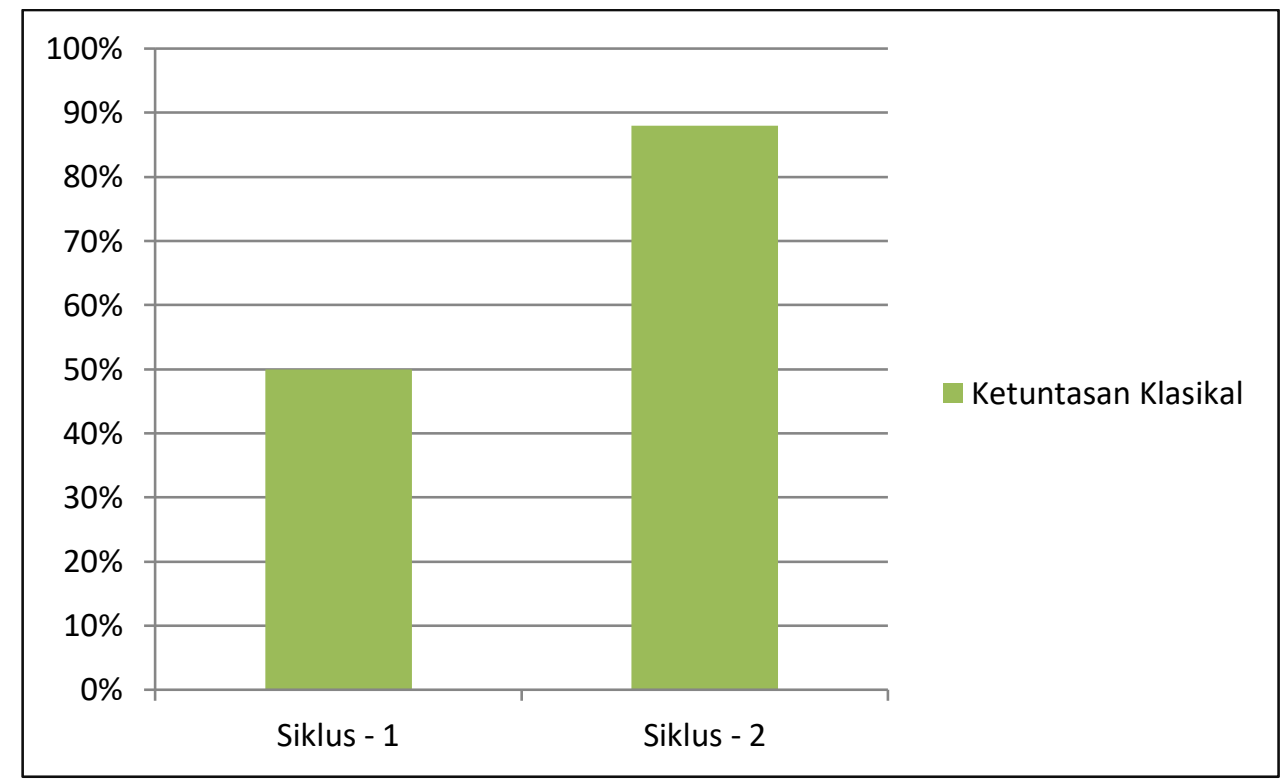

Gambar 2. Hasil perbandingan Ketuntasan Klasikal siklus-1 dan siklus-2

\section{Pembahasan}

Hasil pengamatan Penulis menunjukkan bahwa pembelajaran Pendidikan Agama Islam dan Budi Pekerti terutama untuk meningkatkan Kompetensi Dasar Memahami Makna Tata Krama, Sopan Santun dan Rasa Malu pada peserta didik kelas IX D SMP Negeri 5 Ponorogo Tahun Pelajaran 2021 / 2022 menggunakan Problem Based Learning dengan prosedur sebagai berikut : Dalam kegiatan inti pembelajaran, secara individu peserta didik dapat memahami Kompetensi Dasar Memahami Makna Tata Krama, Sopan Santun dan Rasa Malu. Guru memberikan penilaian terhadap masing-masing peserta didik. Guru dan peserta didik mengadakan refleksi terhadap proses dan hasil belajar. Pada pembelajaran siklus - 1 dengan 
Problem Based Learning ini hasilnya belum memuaskan, karena semua peserta didik masih belum memberikan alternatif jawaban dari problem yang disampaikan kepada mereka. Masing - masing anak hanya memberikan satu jawaban atau solusi dari problem yang disampaikan. Dari jawaban atau solusi yang disampaikan oleh masing - masing peserta didik, memiliki kemiripan antara satu anak dengan yang lain. Hal ini dimungkinkan karena penerapan Problem Based Learning masih merupakan sesuatu yang baru bagi peserta didik sehingga mereka belum terbiasa untuk memberikan alternatif solusi dari problem - problem yang disampaikan kepada mereka.

Hasil wawancara dengan peserta didik juga menunjukkan bahwa mereka masih kesulitan menemukan alternatif jawaban atau solusi dari problem - problem yang disampaikan kepada mereka dan peserta didik menyampaikan bahwa problem yang disampaikan kepada mereka terlalu banyak sehingga peserta didik kekurangan waktu dengan jadwal yang tersedia serta hasil evaluasi tes tulis secara individu juga belum memenuhi kriteria ketuntasan minimal. Kekurangan yang ada pada pertemuan pertama ini diperbaiki pada siklus - 2

Pada siklus - 2 pembelajaran Pendidikan Agama Islam dengan Problem Based Learning ini sudah menunjukkan hasil yang memuaskan. Kegiatan pembelajaran dengan menggunakan Problem Based Learning yang dilaksanakan dengan tahapan dua siklus ini menunjukkan peningkatan keaktifan peserta didik dalam proses pembelajaran Pendidikan Agama Islam terutama pada Kompetensi Dasar dalam Memahami Makna Tata Krama, Sopan Santun dan Rasa Malu pada peserta didik kelas IX D SMP Negeri 5 Ponorogo Tahun Pelajaran 2021 / 2022. Hal ini didasarkan pada pengamatan proses pembelajaran yang mengalami peningkatan keaktifan peserta didik dari siklus -1 ke siklus -2 , juga terbukti adanya peningkatan nilai hasil belajar peserta didik dari siklus - 1 yang rata - rata nilai kelasnya 69 ke siklus - 2 menjadi 81 dan prosentase ketuntasan belajar klasikal dari siklus - 1 sebesar $50 \%$ ke siklus - 2 menjadi $88 \%$

Dari penelitian yang dilaksanakan dengan dua siklus ini dapat disimpulkan bahwa Problem Based Learning dapat meningkatkan keaktifan peserta didik dalam proses pembelajaran sehingga hasil belajar Pendidikan Agama Islam terutama pada Kompetensi Dasar dalam Memahami Makna Tata Krama, Sopan Santun dan Rasa Malu pada peserta didik kelas IX D SMP Negeri 5 Ponorogo Tahun Pelajaran 2021 / 2022 dapat meningkat yang berujung pada pencapaian ketuntasan klasikal. Hal ini didasarkan pada pengamatan proses pembelajaran yang mengalami peningkatan keaktifan peserta didik dari siklus - 1 ke siklus - 2 dan juga adanya peningkatan hasil belajar peserta didik sehingga ketuntasan secara klasikal dapat tercapai, yaitu dengan adanya peningkatan prosentase ketuntasan klasikal dari siklus - 1 sebesar $50 \%$ menjadi $88 \%$ pada siklus - 2. Sebagaimana dinyatakan Fatirul (2020 : 8) bahwa Problem Based Learning merupakan metode pembelajaran yang memberikan kesempatan kepada peserta didik untuk belajar membangun tanggung jawab saat menghadapi permasalahan di dalam kehidupannya, dalam kesehariannya dapat meningkatkan kemandiriannya dalam belajar yang akan berimplikasi pada peningkatan hasil belajar. Pendapat senada disampaikan oleh Amir (2015 : 84) yang menyatakan bahwa proses Problem Based Learning menuntut peserta didik untuk lebih independen dengan fokus belajarnya, semangat bertanggung jawab atas pembelajaran memang harus diusung oleh setiap peserta didik dan nantinya harus bersiap untuk ujian (mendapatkan hasil ujian yang maksimal). Hasil Penelitian Tindakan Kelas ini telah menunjukkan bahwa peserta didik yang mengikuti rangkaian langkah - langkah pembelajaran dengan Problem Based Learning dapat menjadikan peserta didik untuk lebih bertanggung jawab saat menghadapi permasalahan yang dibuktikan dengan lebih aktif dalam mengikuti pembelajarannya, terutama pada langkah ketiga yakni peserta didik mengumpulkan informasi untuk memperoleh data dalam rangka menjawab atau menyelesaikan masalah yang dikaji sehingga hal ini juga dapat meningkatkan hasil belajar dan ketuntasan klasikal dapat terpenuhi. Merujuk pendapat Ngalimun (2016 : 117) yang menjelaskan bahwa Problem Based Learning merupakan salah satu model pembelajaran inovatif yang dapat memberikan kondisi belajar aktif kepada peserta didik dalam upaya meningkatkan kualitas proses pembelajaran dan hasil belajar. Dalam Penelitian ini, penerapan langkah - langkah Problem Based Learning yang memberikan 
peluang kepada peserta didik untuk aktif dalam proses pembelajaran yakni dengan bukti adanya alternatif solusi atau penyelesaian dari problem - problem yang disampaikan kepada peserta didik dan pada akhirnya dapat meningkatkan hasil belajar. Pendapat yang disampaikan oleh Uno (2019 : 153) menyatakan bahwa ketika kita membicarakan kualitas pembelajaran, hal ini berarti mempersoalkan tentang bagaimana kegiatan pembelajaran yang dilakukan selama ini berjalan dengan baik serta menghasilkan keluaran (dari hasil belajar) yang baik pula, penelitian ini telah membuktikan bahwa Problem Based Learning dapat meningkatkan hasil belajar Pendidikan Agama Islam terutama pada Kompetensi Dasar dalam Memahami Makna Tata Krama, Sopan Santun dan Rasa Malu, dengan bukti adanya ketercapaian nilai ketuntasan klasikal. Hasil penelitian Widayanti (2013 : 35) menyebutkan bahwa metode Problem Based Learning dapat meningkatkan aktivitas belajar siswa dan hasil belajar siswa baik dari aspek kognitif, efektif maupun psikomotor. Pendapat yang hampir sama disampaikan oleh Wakiah (2020 : 162) dalam penelitiannya juga menyatakan bahwa penerapan model Pembelajaran Berbasis Masalah pada pembelajaran Matematika materi Perbandingan Trigonometri kelas X di SMKN 1 Sakra Lombok Timur menunjukkan hasil yang baik. Penelitian yang dilakukan oleh Okta (2018 : 94) menjelaskan bahwa penerapan model Pembelajaran Berbasis Masalah pada proses pembelajaran dapat meningkatkan hasil belajar siswa dan meningkatkan aktivitas belajar siswa guna meningkatkan pola pikir siswa untuk memecahkan masalah yang dihadapi secara individu dan kelompok. Hal senada juga disampaikan oleh Apriyanto ( 2017 : 10) yang menyatakan bahwa metode pembelajaran dengan menggunakan model Pembelajaran Berbasis Masalah dapat meningkatkan hasil belajar siswa. Penelitian Tindakan Kelas dengan Problem Based Learning ini juga sudah membuktikan bahwa apa yang menjadi tujuan dari Kompetensi Dasar dalam Memahami Makna Tata Krama, Sopan Santun dan Rasa Malu ini dapat terwujud dengan hasil pada siklus - 2 yang menunjukkan $88 \%$ ketuntasan klasikal dapat terpenuhi. Merujuk pendapat Riyanto (2014 : 286) dalam bukunya Paradigma Baru Pembelajaran menyatakan bahwa dalam Problem Based Learning guru berperan mengajukan problem yang nyata, memberikan dorongan, memotivasi, menyediakan bahan ajar dan fasilitas yang diperlukan peserta didik untuk menyelesaikan permasalahan serta memberikan dukungan dalam upaya meningkatkan temuan dan perkembangan intelektual peserta didik (yang dibuktikan dengan hasil belajar). Dalam Penelitian Tindakan Kelas ini, pendidik juga sudah berperan dalam upaya meningkatkan perkembangan intelektual peserta didik melalui tahapan Problem Based Learning dalam proses pembelajaran Pendidikan Agama Islam terutama pada Kompetensi Dasar Memahami Makna Tata Krama, Sopan Santun dan Rasa Malu pada peserta didik kelas IX D SMP Negeri 5 Ponorogo Tahun Pelajaran 2021 / 2022.

\section{KESIMPULAN}

Berdasarkan hasil penelitian dan pembahasan ini dapat disimpulkan bahwa : Problem Based Learning terbukti dapat meningkatkan hasil belajar Pendidikan Agama Islam terutama pada Kompetensi Dasar Memahami Makna Tata Krama, Sopan Santun dan Rasa Malu pada Peserta Didik Kelas IX D SMP Negeri 5 Ponorogo Jawa Timur Tahun Pelajaran 2021 / 2022. Hal ini dapat ditunjukkan dengan adanya peningkatan keaktifan peserta didik dari siklus - 1 ke siklus - 2 dan juga adanya peningkatan hasil belajar peserta didik sehingga ketuntasan secara klasikal dapat tercapai, yaitu dengan adanya peningkatan nilai rata - rata peserta didik dan prosentase ketuntasan klasikal dari siklus -1 dengan nilai rata - rata 69 dan ketuntasan klasikal sebesar $50 \%$ ke siklus - 2 dengan nilai rata - rata menjadi 81dan ketuntasan klasikal menjadi $88 \%$ 


\section{DAFTAR PUSTAKA}

Akbar Sa'dun. (2009). Penelitian Tindakan kelas, Filosofi, Metodologi \& Implementasi. Yogyakarta: Cipta Media Aksara.

Amir Taufiq M. (2015). Inovasi Pendidikan Melalui Problem Based Learning. Jakarta : Prenadamedia Group.

Apriyanto Bejo. (2017). Penerapan Pembelajaran Berbasis Masalah Untuk Meningkatkan Aktivitas dan Hasil Belajar Siswa dalam Memahami Lingkungan Hidup pada Mata Pelajaran IPS di SMP Negeri 2 Sukodono. Jurnal Pendidikan Ekonomi : Jurnal Ilmiah Ilmu Pendidikan, Ilmu Ekonomi dan Ilmu Sosial volumen 11 Nomor 2 (2017)

Direktorat Jendral Pendidikan Dasar dan Menengah. Direktorat Pembinaan Sekolah Menengah Pertama. (2016). Panduan Penilaian Oleh Pendidik dan Satuan Pendidikan. Jakarta : Kementerian Pendidikan Dan Kebudayaan.

Daryanto, Karim Syaiful. (2017). Pembelajaran Abad 21. Yogyakarta : Gava Media

Fathurrohman M. (2017). Model - Model Pembelajaran Inovatif. Yogyakarta : Ar Ruzz Media Fatirul Noor Achmad. (2020). Strategi Pembelajaran Problem Based Learning. Surabaya : CV. Jakad Media Publishing.

Laksono - Kisyani, Siswono Yuli Eko T. (2018). Penelitian Tindakan Kelas. Bandung : PT Remaja Rosdakarya.

Muhaimin. (2010). Pengembangan Kurikulum Pendidikan Agama Islam di Sekolah, Madrasah dan Perguruan Tinggi. Jakarta : Raja Grafindo Persada.

Namsa Yunus. (2000). Metodologi Pengajaran Agama Islam. Ternate : Pustaka Firdaus.

Ngalimun, Fauzani M, Salabi Ahmad. (2016). Strategi dan Model Pembelajaran. Yogyakarta : Aswaja Pressindo

Okta Dwi Puspira. (2018). Penerapan Model Pembelajaran Berbasis Masalah Untuk Meningkatkan Hasil Belajar IPA. Diklabio : Jurnal Pendidikan dan Pembelajaran Biologo 2 (1) 86 - 95 (2018)

Ramayulis. (2018). Metodologi Pendidikan Agama Islam. Jakarta : Kalam Mulia

Riyanto Yatim. (2014). Paradigma Baru Pembelajaran. Jakarta : Prenadamedia Group.

Uno Hamzah B. (2019). Model Pembelajaran Menciptakan Proses Belajar Mengajar yang Kreatif dan Efektif. Jakarta : Bumi Aksara.

Widodo, Widayanti Lusi. (2013). Peningkatan Aktivitas Belajar dan Hasil Belajar Siswa dengan Metode Problem Based learning pada Siswa Klas VII A MTs Negeri Donomulyo Kulon Progo Tahun Pelajaran 2012 / 2013, Jurnal Fisika Indonesia nomor 49 volume XVII edisi April 2013

Wakiah Wakqoatil. (2020). Peningkatan Hasil Belajar Peserta Didik melalui Penerapan Model Pembelajaran Berbasis Masalah pada Materi Perbandingan Trigonometri di SMK Negeri 1 Sakra , Jurnal Ilmiah Profesi Pendidikan volumen 5 nomor 2 November 2020 